\title{
Analysis of Mobilization Factors, Personal Hygienic, Nutritional Status in Washing Perenium Healing in Women in Lamongan Health and Health Center
}

\author{
Siti Sholikha ${ }^{1}$, Siti farida ${ }^{2}$, \\ Indasah $^{2}$ \\ ${ }^{1}$ Magister of Health Study \\ Program of Institut Ilmu \\ Kesehatan STRADA Indonesia \\ ${ }^{2}$ Lecturer of Institut Ilmu \\ Kesehatan STRADA Indonesia \\ Email: \\ sholikhasiti@gmail.com
}

\begin{abstract}
Perenium rupture is a tear that occurs in the perenium region during labor. Factors that influence the healing of perineal wounds include maternal nutritional needs that are sufficiently seen from the Body Mass Index (BMI), personal hygiene, mothers mobilizing. This study aims to determine the factors that influence the healing of perenium wounds in postpartum mothers at Turi Health Center and Lamongan Health Center in 2018. The research design used is quantitative research using a "cross sectional" approach. The sampling technique used is Simple Rendom Sampling with a sample of 116 respondents. Analysis technique with logistic regression test. The results of the analysis showed that there was a significant influence between the mobilization of p-value $0,000<0,05$, Personal Hygiene p-value 0,009 <0,05, and Nutritional Status p-value 0,009 $<0,05$ with healing of perennial wounds. And also found a significant simultaneous influence between personal hygiene mobilization, and nutritional status of perenium wound healing with a p-value of $0,000<0,05$ with the most dominant factor affecting wound healing is personal hygiene. Mother's personal hygiene helps reduce the source of infection and increases comfort in the mother. By preventing infection in perenium wounds, the wound can heal quickly.
\end{abstract}

Keywords: Mobilization, perenium wound healing, personal hygiene, nutritional status 


\section{INTRODUCTION}

Perenium rupture is a tear that occurs in the perenium region during labor. The perenium is the area between the two thighs, between the vulva and the anus. Perenium plays a role in labor because it is the outside of the pelvic floor. The perenium which is located between the vulva and the anus is $4 \mathrm{~cm}$ on average. (Wiknjosastro, 2013)

Nearly $90 \%$ of all births experience perenium tears, both with and without episiotomy. Usually the healing of wounds in this perenium tear will heal varies, there are those who recover normally and there are those who experience delays in healing, it can be influenced by several factors including maternal characteristics, nutritional status, injury conditions and their care. (Aeiyeyeh, 2013).

In Indonesia perenium wounds were experienced by $75 \%$ of vaginal delivery mothers, in 2013 it was found that out of 1,951 vaginal births of vaginal delivery, $57 \%$ of mothers received perenium sutures in 28\% due to episiotomy and 29\% due to spontaneous tears. (Depkes RI, 2013)

Factors that influence the healing of perineal wounds include maternal abnormalities such as anemia and diabetes mellitus, adequate maternal nutritional needs seen from maternal BMI, maternal knowledge about good maternal perineal wound care, maternal personal hygiene both during the puerperium, mother mobilizing early 2 hours after labor in the mother there are no complications (Prawirohardjo, 2013).

Post-partum early mobilization has become a health problem that increases from year to year, therefore efforts to mobilize are done as early as possible to reduce the prevalence of post partum complications. The usefulness of mobilization that can facilitate blood circulation can also accelerate the healing process of perenium wounds. But often the postpartum mothers are reluctant to mobilize with the pain in the suture wound or fear that the stitches will come off. (Rahayu, 2013)

In addition to personal hygiene mobilization is one of the factors that affect the duration of healing of perennial wounds. One form of personal hygiene is the cleanliness of the vulva. Hygiene of the vulva during the puerperium period must be done, because during the puerperium there is a lot of blood and dirt coming out of the vagina. The vagina is an area that is close to the point of urination and defecation, and is an open organ that makes it easy for germs in the area to spread to the uterus. Infection can occur because postpartum mothers are less diligent in carrying out postpartum care. Mothers are usually afraid to touch the wounds in the perineum so they choose not to clean it, even though in the state of the perineal wound they are susceptible to germs and bacteria so that infection can easily occur. Perineal wounds must be kept clean, by washing the perineum area. Knowledge will help mothers to treat perineal wounds so as to prevent the occurrence of infections in the vulva, perineum, or inside the uterus, and also to maintain the perineal region and vulva jointness (Wiknjosastro, 2013). In postpartum mothers often feel afraid to do the right stroke due to stitching wound pain.

In addition, nutritional factors are also considered to play an important role in the process of wound healing. Mothers who have good nutritional status will experience faster perineal wound healing. Good nutritional status will be achieved if the mother consumes a diverse, nutritious, and balanced diet. Nutrition that is good for the mother of course will benefit the fetus and newborn baby. Malnutrition in general can result in reduced wound strength, increased wound dehiscence, increased susceptibility to infection and poor quality scarring. Certain nutrient deficiencies can affect healing. (Arisman, 2013)

Based on the data obtained in the delivery room of the Lamongan Health Center in November 2018. The number of mothers giving birth as many as 106 mothers, there were 92 mothers experiencing rupture of the second degree perineum. (PKM Turi Register Data, 2018).

While in Lamongan Public Health Center the number of mothers giving birth was 98 mothers and there were 72 mothers having first degree rupture and 37 mothers experiencing second degree rupture (PKM Lamongan Data Register, 2018).

Based on the results of preliminary interviews of 10 mothers who experienced perineal rupture in the delivery room of Lamongan Health Center there were 8 mothers who experienced faster perineal wound healing including 3 mothers had good nutrition, 4 mothers performed good personal hygiene as recommended by midwives, and 2 other mothers mobilized .2 mothers who experience healing perineal wounds are slower because mothers should not get out of bed even though the mother has been declared to have no abnormalities and may carry out early mobilization. 
Based on the background above, the authors are interested in conducting research with the title "Analysis of Mobilization Factors, Personal Hygiene, and Nutritional Status of Healing Perenium Wounds in Postpartum Mothers in the Turi Health Center and Lamongan Health Center.".

\section{METHODS}

The research design is descriptive analytic using a cross sectional study design (cross sectional study). (Arikunto, 2013) The independent variables in this study were mobilization, personal hygiene, nutritional status while the dependent variable in this study was healing of perennial wounds. The population of this study were all postpartum mothers with perenium wounds in the working area of the turi health center and the lamongan health center with 164 mothers. The sample was taken by simple sampling technique as many as 116 respondents. Data was collected with quisioner instruments and processed in editing, coding, scoring and tabulating and tested by logistic regression test. The implementation starts on 1-31 2018. The assessment of each variable can be explained in the following way:

1. Mobilization

a. Mobilize if $x \geq \bar{x}$

b. Do not mobilize if $\mathrm{x} \leq \overline{\mathrm{x}}$

2. Personal Hygiene

a. Do personal hygiene if $x \geq \bar{x}$

b. Do not do personal hygiene if $x \leq \bar{x}$

3. Nutritional status

a. Normal Nutritional Status BMI $=18.5-25.0$

b. More BMI Nutritional Status $>25$

c. Nutritional Status Less BMI $<18.5$

4. Healing Perenium Wounds

a. Fast wound healing if $\leq 6$ days

b. Wound healing is slow if $>6$ days

RESULTS

Table 1. Omnimbus Analysis of Mobilization Factor Test, Personal Hygiene, and Nutritional Status by Healing Perenium Wounds in Postpartum Mothers with Perenium Wounds in the Work Area of Turi Health Center and Lamongan Health Center in December 2018

\begin{tabular}{llcrr}
\hline \multicolumn{5}{c}{ Omnibus Tests of Model Coefficients } \\
\hline Step 1 & Chi-square & df & \multicolumn{1}{c}{ Sig. } \\
& Step & 149,451 & 3 &, 000 \\
& Block & 149,451 & 3 &, 000 \\
& Model & 149,451 & 3 &, 000 \\
\hline
\end{tabular}

Omnimbus Test is used to answer the simultaneous effect of Independent variables on the dependent variable. The interpretation of data for table 1 can be seen that the value of $\mathrm{P}$ value Chi Square $0,000<\alpha=0.05$ and the value of X2 count $149,451>\mathrm{X} 2$ table with df $3=7,815$ so that $\mathrm{H} 0$ is rejected and $\mathrm{H} 1$ is accepted means that there is a significant influence simultaneously between mobilization factors, personal hygiene, and nutritional status for healing wound perenium.

Table 2. Pseudo R Square Mobilization, Personal hygiene, and Nutritional Status Factors with Healing of Perenium Wounds in Postpartum Mothers with Perenium Wounds in the Work Area of Turi Health Center and Lamongan Health Center in December 2018

\begin{tabular}{lccc}
\hline \multicolumn{4}{c}{ Model Summary } \\
\hline Step & -2 Log likelihood & $\begin{array}{c}\text { Cox \& Snell R } \\
\text { Square }\end{array}$ & $\begin{array}{c}\text { Nagelkerke R } \\
\text { Square }\end{array}$ \\
\hline 1 &, $000^{\mathrm{a}}$ &, 724 & 1,000 \\
\hline a. Estimation terminated at iteration number 20 & because maximum \\
iterations has been reached. Final solution cannot be found. & \\
\hline
\end{tabular}


Table 2 shows that the ability of the independent variable to explain the dependent variable is $100 \%$ as seen from the Nagelkerke Square value of 1,000. So that there are no other factors outside the independent variable that can explain the dependent variable

Table 3. Logistic Regression Mobilization Factors, Personal Hygiene, and Nutritional Status with Healing of Perenium Wounds in Postpartum Mothers with Perenium Wounds in the Work Area of Turi Health Center and Lamongan Health Center in December 2018

\begin{tabular}{|c|c|c|c|c|c|c|c|c|c|}
\hline \multicolumn{10}{|c|}{ Variables in the Equation } \\
\hline & & \multirow[t]{2}{*}{ B } & \multirow[t]{2}{*}{ S.E. } & \multirow[t]{2}{*}{ Wald } & \multirow[t]{2}{*}{ df } & \multirow[t]{2}{*}{ Sig. } & \multirow[t]{2}{*}{$\operatorname{Exp}(B)$} & \multicolumn{2}{|c|}{$\begin{array}{c}\text { 95\% C.I.for } \\
\text { EXP(B) }\end{array}$} \\
\hline & & & & & & & & Lower & Upper \\
\hline \multirow{4}{*}{$\begin{array}{l}\text { Ste } \\
\text { p } 1^{\text {a }}\end{array}$} & Mobilisasi & 36,893 & ,452 & 8,526 & 1 &, 000 & 4,053 & 1,200 & 14,320 \\
\hline & Personal & 37,020 & ,460 & 16,301 & 1 & ,009 & 8,495 & 2,560 & 15,310 \\
\hline & Gizi & 36,678 & 546 & 4,638 & 1 & ,009 & 3,956 & 1,230 & 14,670 \\
\hline & Constant & $\begin{array}{c}- \\
165,673\end{array}$ & ,173 & 25,578 & 1 & , 000 & 297 & & \\
\hline
\end{tabular}

\section{The results of the regression analysis refer to the probability values as follows}

Mobilization has a significance value of $0,000<0.05$ so that $\mathrm{H} 0$ is rejected or which means mobilization has a significant partial effect on the healing of perennial wounds.

Personal hygiene has a significance value of $0.009<0.05$ so that $\mathrm{H} 0$ is rejected or meaning Personal Hygiene has a significant partial effect on healing of perennial wounds.

Nutritional Status has a significance value of $0.009<0.05$ so that $\mathrm{H} 0$ is rejected or which means Nutritional Status has a significant partial effect on the healing of perennial wounds.

Based on OR value or EXP (B), it can be seen that Personal Hygiene has the highest EXP (B) value of 8,495 among other independent variables so that it can be interpreted as the personal hygine because personal hygiene can affect perenium wound healing 8,495 times. And if seen from the value of $\mathrm{B}$, it can be seen that all B values of the independent variables are positive, this indicates that all independent variables have a positive relationship with wound healing

\section{DISCUSSION}

\section{Effect of Mobilization on Healing Perenium Wounds in Postpartum Mothers in Turi Health Center and Lamongan Health Center}

Based on the results of logistic regression analysis, the significance value of mobilization was $0,000<\alpha=0.05$, so that $\mathrm{H} 0$ was rejected and $\mathrm{H} 1$ was accepted. Besides that the results of the study also showed the number of mothers who mobilized as many as 69 people and 60 of them were aged 20-35 years, 50 people had high school education, and 57 were housewives. The definition of mobilization is the ability of someone to walk, get up, stand up and go back to bed, chair, toilet seat, and so on besides the ability to move the upper limb. (Liana, 2013).

The results of this study are supported by previous research conducted by Fithriany, Hasrati Hasan, and Cut Yuniwati in 2014 with the title Relationship of mobilization in post partum mothers with healing of perennial wounds at the Aceh Government maternal and child hospital BLUD results of Chi-Square statistical tests value of p-value $0.020<0.05$ so it was concluded that there was a relationship between mobilization and healing of perennial wounds in the Aceh Government Mother and Child BLUD.(Fitriani, 2014)

The process of wound healing is closely related to blood circulation. Areas that have wounds require a good supply of oxygen and blood to speed up the wound healing process, by mobilizing the blood circulation to return to its original function after labor and adaptation to pregnancy.

Postpartum mothers who mobilize are expected to be able to obtain all the benefits of mobilization and be able to regain their independence to gradually carry out physical activities, and the most important thing is to be able to care for their own babies. Most of the respondents in this study 
had mobilized and one of their biggest reasons was because they wanted to be able to care for their babies independently but there were still some who had not mobilized on the grounds that they were afraid of open stitching and pain. Because of this fear some mothers limit their movements. Besides that there are some restrictions from parents to postpartum mothers related to mobilization for example having to walk with the foot position in a meeting and with short steps, this will obviously hinder the mobilization process that must be carried out by postpartum mothers.

\section{Effect of Personal Hygiene on Healing Perenium Wounds in Postpartum Mothers in Turi Health Center and Lamongan Health Center}

Based on the results of the Logistic Regress analysis obtained a significance value of $0.009<\alpha=$ 0.05 , so that $\mathrm{H} 0$ is rejected and H1 is accepted, it can be concluded that Personal hygiene gives a significant partial effect on healing of perenium wounds in postpartum mothers at Turi Health Center and Lamongan Health Center. Besides that the results of the study also showed the number of mothers who carried out personal hygiene as many as 68 people and 60 of them aged 20-35 years, 49 people with high school education, and 53 housewives. Hygiene of a person is an action to maintain cleanliness and personal health for physical and psychological well-being. Personal hygiene of postpartum helps reduce the source of infection and increases comfort in the mother.

The results of this study are supported by previous research conducted by Yulia Handayani (2014) after a Chi-Square test with a confidence level of 95\% was obtained when the value of p-value $0.001<\alpha=0.05$. With the conclusion that there is an influence between personal hygiene on healing of perenium wounds in postpartum mothers at the Regional General Hospital Dr. Zaenoel Abididn Banda Aceh.(Handayani, 2013)

The effect of personal hygiene on perenium wound healing shows that with good personal hygiene and correctness, wound healing can run quickly. The human body is susceptible to infection from germs or microorganisms around us, especially the perenium region which tends to be moist. All open parts of the body are the entry points for infectious germs as well as perennial wounds. By maintaining personal hygiene it will suppress the possibility of entry of germs through perenium wounds so that they can prevent infection and cure wounds can run quickly.

\section{Effect of Nutritional Status on Healing Perenium Wounds in Postpartum Mothers In Turi Health Center and Lamongan Health Center}

Based on the results of the Logistic Regression analysis, a significance value of $0.009<\alpha=0.05$ was obtained, so $\mathrm{H} 0$ was rejected and $\mathrm{H} 1$ was accepted, it can be concluded that the nutritional status gave a significant partial effect on perenium wound healing in postpartum mothers at Turi and Lamongan City Health Centers. Besides that the results of the study also showed the number of mothers who had normal nutritional status as many as 84 people and 72 of them were aged 20-35 years, 65 people had high school education, and 70 were housewives. Nutritional status is a measure of the condition of a person's body which can be seen from the food consumed and the use of nutrients in the body. Nutritional status is divided into three categories, namely malnutrition status, normal nutrition, and over nutrition (Fraser, 2013)

The results of this study were also supported by research conducted by Elida Fitri entitled "Factors That Affect the Length of Healing of Perineal Wounds in Postpartum Mothers at Dr. General Hospital. Zainoel Abidin Banda Aceh in 2013 "where conclusions based on the results of statistical tests found a relationship between nutritional status and the duration of recovery of perennial wounds.(Fitri, 2013)

The effect of nutritional status on healing perenium wounds shows that normal nutritional status is obtained with good nutritional intake, with good nutritional intake is needed by postpartum mothers, because during the puerperium the mother's body works hard to restore reproductive organs physiology and return to normal state before pregnant. In addition, postpartum mothers also carry out a lactation process that also requires large amounts of energy. 


\section{Mobilization, Personal Hygiene, and Nutritional Status Results with Healing of Perenium Wounds in Postpartum Mothers at Turi Health Center and Lamongan Health Center}

The influence of mobilization factors, personal hygiene, and nutritional status on the healing of perenium wounds was simultaneously known from the significance value of Omnimbus Test which showed $\mathrm{p}$-value $=0,000<\alpha 0,05$ and X2 count $=149,451>\mathrm{X} 2$ table $=7,815$ so that $\mathrm{H} 0$ was rejected and $\mathrm{H} 1$ accepted which means that there is a significant simultaneous influence between mobilization, personal hygiene, and nutritional status on perenium wound healing in postpartum mothers with perenium wounds at Turi Health Center and Lamongan Health Center, and the most influential is personal hygiene factors. Besides that the results of the study also showed the number of mothers who experienced rapid wound healing as many as 76 people and 66 of them were aged 20-35 years, 57 people had high school education, and 62 were housewives.

Factors that cause puerperal infection can come from injury to the birth canal which is a good medium for the development of germs. This is caused by the mother's low endurance after giving birth, poor maintenance and poor hygiene. The appearance of infection in the perineum can propagate in the bladder tract or on the birth canal. Handling the slow complications can lead to the death of post partum mothers considering the condition of the post partum mother is still weak (Wiknjosastro, 2013)

One of the inhibitors of healing perenium wounds is the appearance of infection in the wound. Infection is closely related to cleanliness. With good personal hygiene, it is expected that germs, bacteria and microorganisms in the environment around us cannot enter and infect our bodies. There are so many pathways to enter germs and microorganisms into our bodies, one of which is a wound. Because the wound causes the skin and blood vessels to open so that germs or microorganisms can easily enter and infect the body. Humid areas are also a breeding ground for germs and microorganisms.

Perenium suture including the entrance of microorganisms and germs, especially this wound is located in a place that tends to be moist. To prevent it, good personal hygiene is needed. The cleanliness and humidity of the perenium and vulva must always be maintained to prevent the entry of germs or microorganisms that cause infection.

\section{CONCLUSION}

Most $(59.5 \%)$ postpartum mothers with perenium wounds at the Turi Health Center and Lamongan Health Center mobilize. Most (58.6\%) postpartum mothers with perenium wounds at Turi Health Center and Lamongan Health Center do personal hygiene.

Most $(72.4 \% \%)$ postpartum mothers with perenium wounds at Turi Health Center and Lamongan Health Center have normal nutritional status. Most (65.5\%) postpartum mothers with perenium wounds at the Turi Health Center and Lamongan Health Center experience relatively fast perenium wound healing.

Based on the results of logistic regression test, it is known from the significance value of Omnimbus Test which shows $\mathrm{p}$-value $=0,000<\alpha 0,05$ and the value of $\mathrm{X} 2$ count $=149,451>\mathrm{X} 2$ table $=7,815$ so that $\mathrm{H} 0$ is rejected and $\mathrm{H} 1$ is accepted which means there are significant simultaneous influences between mobilization factors, personal hygiene, and nutritional status for healing wound perenium. the most dominant factor influencing is personal hygiene with the highest EXP (B) value from other factors.

\section{SUGGESTION}

For Puskesmas

To provide input for puskesmas to continue to improve counseling about influencing healing mobilization, personal hygiene, and nutritional status of perenium wounds in postpartum mothers. In addition, counseling should be carried out when the mother is in pregnancy so that when the puerperium period the mother understands what must be done and counseling is not only given to postpartum mothers but also to families, especially families who live at home with the mother. When counseling needs to be emphasized the effects that will be experienced by the mother when mobilizing or percent hygiene include the occurrence of pain or pain but it is normal and will not make the suture open. 


\section{For Further Researchers}

The next researcher is expected to examine other variables such as age, knowledge, use of antibiotics and so on so that this study can be improved by expanding the area of research with a larger number of samples so that the results obtained will be more likely to generalize to large populations and get results better and more accurate so that researchers can provide appropriate solutions in accordance with existing environmental conditions.

\section{For Respondents}

This study can provide input to postpartum mothers to find out several factors that influence the healing of perennial wounds.

\section{For the community}

The general public can know that mobilization, personal hygiene, and nutritional status can affect healing of perennial wounds. Thus it is expected that the public can know what is permissible and not allowed to be done so that they can get wound healing quickly.

\section{REFERENCES}

Arikunto, Suharsimi. 2013. Prosedur Penelitian Suatu Pendekatan Prektek. Jakarta:Rineka Cipta.

Arisman. MB, 2013. Gizi dalam Daur Kehidupan. Jakarta : Mitra Cendikia Offset.

Depkes RI. 2013. Asuhan Persalinan Normal. Jakarta: JHPIEGO

Fitrhriany. 2014. Hubungan Mobilisasi Pada Ibu Post Partum dengan Penyembuhan Luka Perenium di BLUD RSIA Pemerintah Banda Aceh. Skripsi

Fitri, Elida. 2013. Faktor-faktor yang mempengaruhi penyembuhan luka perenium pada ibu nifas du RSUD Dr. Zaenal Abidin Banda Aceh. Skripsi

Fraser, Diane M and Cooper,Margaret A. 2013. Myles Buku Ajar Bidan Myles Buku Ajar Bidan ed.14 alih bahasa Sri Rahayu, Jakarta: EGC

Handayani, yulia. 2014. Pengaruh Personal Hygiene Terhadap Penyembuhan Luka Perenium Pada Ibu Nifas Di RSUD Dr. Zaenoel Abidin Banda Aceh. Skripsi

Liana. 2013. Kebutuhan dasar Masa Nifas. http://bidanliana.blogspot.com/ diakses tanggal [19 September 2018]

Rahayu, A. 2013. Hubungan gizi dan personal hygiene dengan perawatan luka perineum pada ibu nifas di Rumah Sakit Boromeus. Skripsi

Winkjosastro. 2013. Ilmu Kandungan. Jakarta : Bina Pustaka 